УДК 66.047

\title{
ДОСЛІДЖЕННЯ ТА ОПТИМІЗАЦІЯ ТЕПЛОТЕХНОЛОГІЧНИХ ПАРАМЕТРІВ ПРОЦЕСУ ОТРИМАННЯ СУХОЇ ФОРМИ ГІДРОЛІЗОВАННОГО БІЛКОВОГО ПРОДУКТУ МЕТОДОМ РОЗПИЛЮВАННЯ
}

\author{
Шаркова Н.О., канд. техн. наук, Турчина Т.Я., канд. техн. наук, Жукотський Е.К. \\ Інститут технічної теплофізики НАН України, вул. Желябова, 2а, м. Київ, 03680, Україна
}

Вивчено вплив температурних режимів розпилювального сушіння на вихід порошку з сушильної камери та його характеристики.
Изучено влияние температурных режимов распылительной сушки на выход порошка из сушильной камеры и его характеристики.
An influence of temperature regimes of spray drying on the powder yield from the drying chamber and its characteristics are studied.

Бібл. 3, рис. 3, табл. 2.

Ключові слова: гідролізовані білкові продукти, розпилювальне сушіння, температура теплоносія, вихід порошку.

$T_{\mathrm{px}}$ - температура теплоносія на вході в камеру;

$T_{\text {вих }}^{\text {вх }}$ - температура теплоносія на виході з камри;

$W_{\text {кін }}^{\text {вих }}$ - кінцева вологість висушеного порошку;

Сучасні інноваційні рішення в галузі технічної теплофізики дозволили вперше в Україні створити технологію отримання нового гідролізованного білкового продукту спеціального дієтичного призначення для застосування при важких захворюваннях, пов'язаних з білковою недостатністю.

Виробництво такого продукту у порошковій формі, зручній для використання та тривалого зберігання, вимагає наукового обгрунтування раціональних теплотехнологічних параметрів його одержання на розпилювальних сушарках 3 урахуванням його фізико-хімічних властивостей. Необхідність таких досліджень обумовлена впливом властивостей кожного висушуваного матеріалу на кінетику його сушіння та міцністні властивості висушених часток, які визначають:

- структурно-механічні характеристики порошку і вільний вихід його з сушильної камери;

- кінцеву вологість та гігроскопічні характеристики порошку, від яких залежать умови та термін його зберігання;

- відновлювальну здатність, зокрема, розчинність [\%] порошку, що служить одним 3 показників якості готового продукту. $\beta$ - кут природного укосу;

$\delta_{\text {сер }}-$ середній лінійний розмір часток порошку; $\rho-$ насипна густина порошку.

Дослідження кінетики сушіння крапель водних розчинів білкових сумішей 3 різним співвідношенням білків рослинного та тваринного походження, які проводились на експериментальному стенді в потоці теплоносія на системі «крапля-парогазове середовище» [1], дали можливість оцінити геометричні, морфологічні, термопластичні і адгезійні характеристики висушених часток в потоці теплоносія і після їх охолодження до $40 \ldots 20{ }^{\circ} \mathrm{C}[2,3]$. Було встановлено, що:

- завдяки термостійкості матеріалу доцільно застосовувати температури теплоносія більше $180{ }^{\circ} \mathrm{C}$, що дозволяє покращити умови висушування часток порошку за рахунок підвищення паропровідних властивостей їх структурованого поверхневого шару і скоротити час їх сушіння у 1,5 рази;

- збереження цілісності часток в процесі багаторазового інтенсивного їх роздування в стадії кипіння свідчить про високі міцністні властивості матеріалу і зниження вірогідності утворення дрібнодисперсної фракції порошку та втрат його з відпрацьованим теплоносієм в умо- 
вах сушарки;

- підвищення монолітності висушених часток сприяє покращенню структурно-механічних характеристик порошку i дозволяє збільшити його загальний вихід 3 камери сушарки.

Мета роботи - визначення раціональних теплотехнологічних параметрів процесу сушіння для збільшення виходу порошку гідролізова- ного білкового продукту з камери розпилювальної сушарки та забезпечення його високої якості.

Дослідження проводились на експериментальній розпилювальній сушарці (рис. 1) прямоточного типу з сушильною камерою циліндроконічного форми діаметром 1,3м, верхнім підводом теплоносія і продуктивністю до 10 кг/ год по випареній волозі [1].

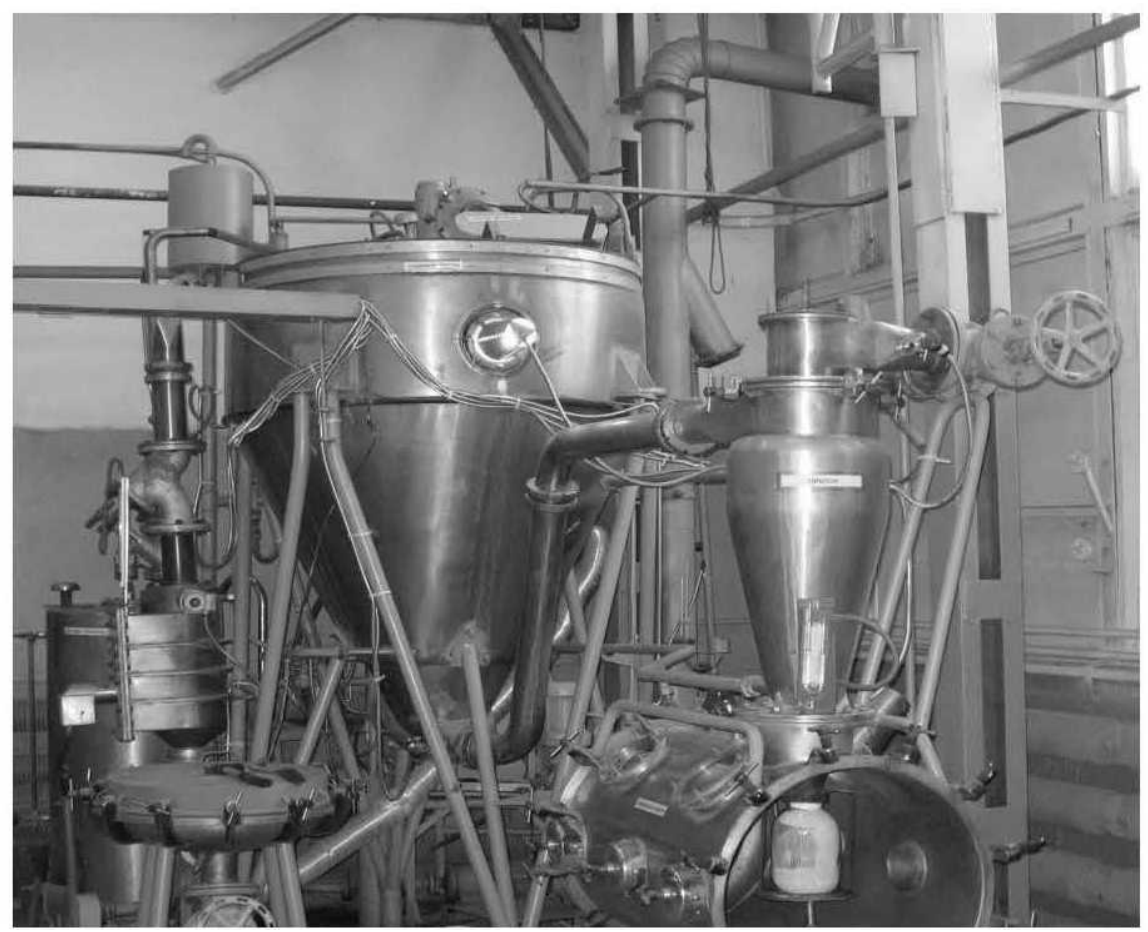

Рис. 1. Загальний вигляд експериментальної розпилювальної сушарки (ІТТФ НАН України).

Підготовлені партії водного розчину гідролізованного білкового продукту 3 певним співвідношенням білкових складових та вмістом сухих речовин, наведених в роботі [3], подавались на відцентровий дисковий розпилювач розпилювальної сушильної установки за допомогою плунжерного насосу у режимі постійного перемішування.

3 урахуванням результатів досліджень кінетики сушіння крапель розчину гідролізованного білкового продукту було запропоновано процес його розпилювального висушування здійснювати при температурах теплоносія на вході в камеру вище $180{ }^{\circ} \mathrm{C}$. Для проведення досліджень були обрані температурні режими, наведені в таблиці 1.

Після виходу температури теплоносія на вказані режими (табл. 1) в камеру подавався водний розчин гідролізованного білкового продукту, де він висушувався до стану сухого порошку і в складі двофазного потоку пневмотранспортом спрямовувався до циклону для його сепарації та вивантаження до приймальної ємності. По завершенні досліду внутрішні поверхні сушильної камери обстежувались на наявність відкладень порошку або адгезійних налипань.

Так, в умовах I температурного режиму процесу сушіння на стінках камери осідав по-рошок, який при простукуванні частково осипався, а в зоні дискового розпилювача налипав, в результаті чого загальний вихід порошку 3 камери складав $<90 \%$, як видно на рис. 2.

За умов II і III режимів процесу сушіння основна маса порошку своєчасно надходила до 
приймальної ємності. Решта порошку, що осідав на стінки камери, легко осипався при періодичному іiі простукуванні. По завершенні процесу сушіння стінки камери були чисті, а вихід порошку складав $\sim 95 \%$ (рис. 2).
Дослідні партії порошків гідролізованного білкового продукту були досліджені за показниками кінцевої вологості та структурномеханічними характеристиками (табл. 2).

Табл. 1. Діапазони температур теплоносія на вході в камеру розпилювальної сушарки та іiі виході при сушінні водного розчину гідролізованного білкового продукту

\begin{tabular}{|c|c|c|c|c|c|}
\hline \multicolumn{5}{|c|}{ Температурні режими сушіння } \\
\hline \multicolumn{2}{|c|}{ I } & \multicolumn{2}{c|}{ II } & \multicolumn{2}{c|}{ III } \\
\hline$T_{\mathrm{Bх}}{ }^{\circ}{ }^{\circ} \mathrm{C}$ & $T_{\text {вих }},{ }^{\circ} \mathrm{C}$ & $T_{\text {вх }},{ }^{\circ} \mathrm{C}$ & $\ddot{e} M T_{\text {вих }},{ }^{\circ} \mathrm{C}$ & $T_{\text {вх }},{ }^{\circ} \mathrm{C}$ & $T_{\text {вих }},{ }^{\circ} \mathrm{C}$ \\
\hline$\leq 185$ & $\leq 82$ & $\leq 190$ & $\leq 87$ & $\leq 195$ & $\leq 92$ \\
\hline
\end{tabular}

Табл. 2. Характеристика дослідних партій порошків гідролізованного білкового продукту, отриманих за різних температурних режимів процесу розпилювального сушіння

\begin{tabular}{|c|c|c|c|c|c|}
\hline $\begin{array}{l}\text { Режи- } \\
\text { ми су- } \\
\text { шіння }\end{array}$ & $\begin{array}{c}\text { Зовнішній } \\
\text { вигляд } \\
\text { порошку }\end{array}$ & $\begin{array}{c}\text { Вологість } \\
\text { порошку } \\
W_{\text {кін }} \% \\
\end{array}$ & $\begin{array}{c}\text { Кут } \\
\text { природно- } \\
\text { го укосу, } \\
\beta^{\circ} \\
\end{array}$ & 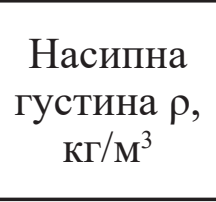 & $\begin{array}{c}\text { Середній } \\
\text { розмір час- } \\
\text { ток порошку } \\
\delta_{c e n}, \text { мкм }\end{array}$ \\
\hline $\mathbf{I}$ & $\begin{array}{l}\text { Білий, схильний до грудкування } \\
\text { та відкладень }\end{array}$ & 4,5 & 35 & 300 & 16 \\
\hline II & Білий, однорідний, сипкий & 4,0 & 37 & 280 & 12 \\
\hline III & $\begin{array}{l}\text { Жовтішого відтінку, однорідний, } \\
\text { сипкий }\end{array}$ & 3,8 & 38 & 270 & 10 \\
\hline
\end{tabular}

Дослідження показали, що отримані партії порошків, запакованих у двошарові поліетиленові пакети, при зберіганні у сухому прохолодному місті без доступу світла не втрачають своїх структурно-механічних характеристик до 1 року за виключенням порошку, отриманого за умов I температурного режиму (табл. 2), який проявляв схильність до грудкування.

Аналіз показників кінцевої вологості $W_{\text {кін }}$ та кута природного укосу $\beta^{\circ}$ (табл. 2) дослідних партій порошків показав, що підвищення температурних режимів сушіння до $190 \ldots 195{ }^{\circ} \mathrm{C}$ (III режим) сприяє зниженню вологості до 3,8 $\%$ та покращенню сипкості порошку, про що свідчить збільшення його виходу (рис. 2).

Враховуючи високу ступінь дисперсності отриманих порошків гідролізованного білкового продукту $\left(\delta_{\mathrm{s}}\right)$ та їх низьку насипну густину ( ) (табл. 2), характерну для порошків знежирених білкових продуктів, отриманих методом розпилювання, важливо відзначити, що для покращення сепараційних властивостей порошку доцільно вміст сухих речовин у вихідному розчині гідролізованного білкового продукту, що подається в розпилювальну сушарку, збільшити у 2-3 рази.

На рис. 2 наведені гістограми виходу 3 сушильної камери дослідних партій порошку гідролізованного білкового продукту, аналіз яких у сукупності із даними табл. 2 показує, що підвищення температурних режимів процесу розпилювального сушіння сприяє збільшенню виходу продукту 3 сушарки. Проте, зайве підвищення температурних режимів процесу сушіння негативно впливає на якісні характеристики порошку, як це відбулось 3 порошком, отриманим за умов III режиму, про що свідчить його більш жовтіший відтінок (табл. 1) та зниження відсотку його розчинності (рис. 3). 


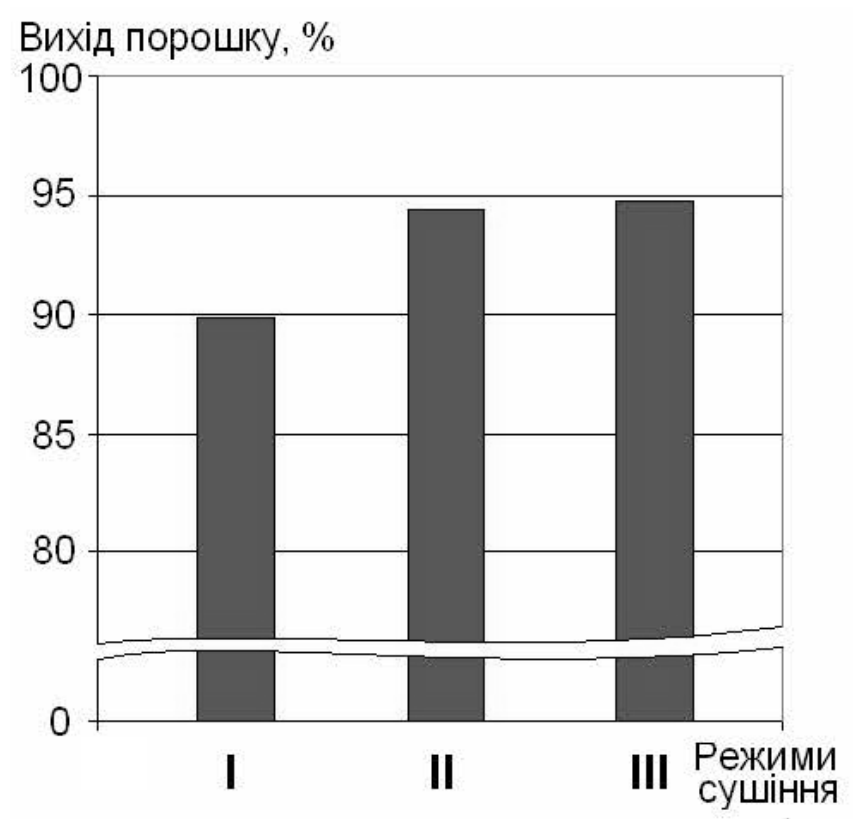

\section{Рис. 2. Гістограми загального виходу порошкового білкового продукту з розпилювальної сушарки за різних температурних режимів сушіння.}

Таким чином, найбільший вихід сухої форми гідролізованного білкового продукту з сушарки та найкращі його характеристики забезпечуються за умов саме II температурного режиму процесу сушіння, який можна вважати раціональним для умов експериментальної розпилювальної сушарки.

За встановленими теплотехнологічними параметрами на даній експериментальні розпилювальній сушарці були проведені роботи по напрацюванню дослідних партій сухої форми гідролізованного білкового продукту. Отриманий порошковий продукт досліджувався за фізико-хімічними, органолептичними та мікробіологічними характеристиками, які у подальшому були використані при розробці технічних умов на промислове виробництво сухої форми даного продукту.

\section{Висновки}

Результатами досліджень по отриманню сухої форми гідролізованного білкового продукту на експериментальній розпилювальній сушарці підтверджена доцільність проведення процесу його сушіння при температурах теплоносія

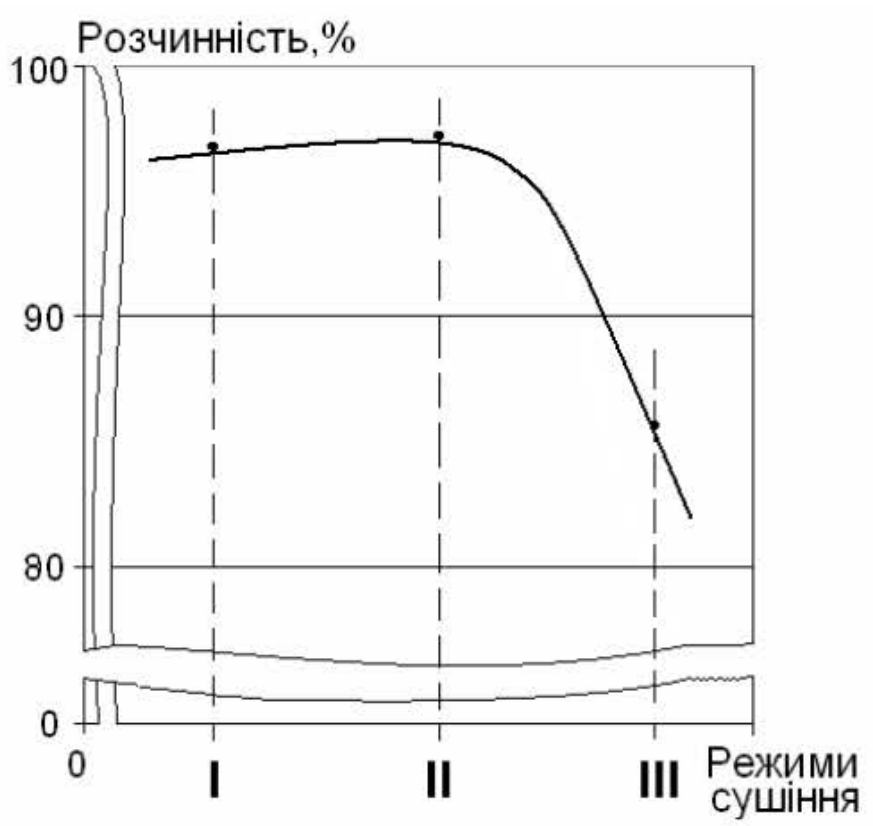

\section{Рис. 3. Розчинність [\%] порочків білкового продукту, отриманих за різних температурних режимів розпилювального сушіння.}

на вході в сушильну камеру вище $180{ }^{\circ} \mathrm{C}$, що покращує умови його висушування завдяки термостійкості та поліпшеним структуруючим та паропровідним властивостям матеріалу.

Встановлені на експериментальній розпилювальній сушарці раціональні теплотехнологічні параметри процесу отримання сухої форми гідролізованного білкового продукту забезпечують високі якісні характеристики продукту 3 терміном зберігання до 1 року.

\section{ЛІТЕРАТУРА}

1. Долинский А.А., Малеикая К.Д., Шморгун В.B. Кинетика и технология сушки распылением. - К.: Наукова думка. - 1987. - 224 с.

2. Шаркова Н.О. Дослідження кінетики сушіння крапель водних розчинів білкових композицій / Н.О. Шаркова, Е.К. Жукотський, Т.Я. Турчина и др.// Наукові праці ОНАХТ. Одеса, 2013. - Вип. 43, Т. 2. - С. 50-52.

3. Турчина Т.Я. Исследование влияния состава белковых композиций на кинетику их сушки в диспергированном состоянии / Т.Я. Турчина, Э.К. Жукотский, А.В. Декуша, 
//Сб. материалов 5-й Межд. науч.-практ. симпозиума «Современные энергосберегающие тепловые технологии (Сушка и термовлаж- ностная. обработка материалов)». (СЭТТ-2014), г. Иваново (Россия), 2014. - Т.1, Секция 3. C. 271-274.

\section{RESEARCH AND OPTIMIZATION OF HEAT TECHNOLOGICAL PARAMETERS FORMS OF OBTAINING DRY HYDROLYZED PROTEIN PRODUCT BY SPRAYNG}

Sharkova N.O., Turchina T.Ya., Zhukotsky E.K.

Institute of Engineering Thermophysics of the National Academy of Sciences of Ukraine, vul. Zhelyabova, 2a, Kyiv, 03680, Ukraine

The article presents experimental data of researching spray drying process of aqueous solution of hydrolyzed protein product in different temperature coolant ranges. Established rational thermal technological parameters of dry form obtaining of hydrolyzed protein product at spray dryer, which provide improvement of structural and mechanical characteristics of the powder, increase its output from the camera of the spray dryer to $93 . .95 \%$ and provide high quality product.
References 3, tables 2, figures 3.

Key words: hydrolyzed protein products, spray drying, coolant temperature, output of powder.

1.Dolynskyy A.A.MaletskayaK.D., Shmorgun V.V. Kinetics and spray-drying technology. - Kyiv: Naukova Dumka. - 1987. - 224 p.

2. Sharkova N.O. The study of the kinetics of drying drops of water solutions of protein compositions / N.O. Sharkova, L.Yu. Avdeeva, E.K. Zhukotskyy, T.Ya.Turchyna, G.V. Dekusha, L.A. Kostyanets, A.V. Tkachenko // Proceedings ONAFT. - Odessa, 2013. - Vol. 43, T. 2. - P. 50-52.

3. Turchyna T.Ya. Investigation of protein composition influence on drying kinetic in dispersed condition / T.Ya. Turchyna, E.K. Zhukotsky, A.V. Dekusha // Sat. materials of 5th int. scientific and practical symposium «Energy-saving technologies for drying and hydrothermal prosessing (DHTP2014)», Ivanovo (Russia), 2014. - Vol. 1, Section 3. - P. 271-274.

Получено 02.06.2015 Received 02.06.2015 